materials with applications including chemical sensing, separation, catalysis, high-density data storage and photonic materials.

Received 14 October; accepted 21 December 2004; doi:10.1038/nature03310.

1. Spatz, J. P. et al. Ordered deposition of inorganic clusters from micellar block copolymer films Langmuir 16, 407-415 (2000).

2. Lopes, W. A. \& Jaeger, H. M. Hierarchical self-assembly of metal nanostructures on diblock copolymer scaffolds. Nature 414, 735-738 (2001).

Pai, R. A. et al. Mesoporous silicates prepared using preorganized templates in supercritical fluids. Science 303, 507-510 (2004).

4. Templin, M. et al. Organically modified aluminosilicate mesostructures from block copolymer phases. Science 278, 1795-1798 (1997).

5. Liang, H. J., Angelini, T. E., Ho, J., Braun, P. V. \& Wong, G. C. L. Molecular imprinting of biomineralized CdS nanostructures: Crystallographic control using self-assembled DNA-membrane templates. J. Am. Chem. Soc. 125, 11786-11787 (2003).

6. Li, M., Schnablegger, H. \& Mann, S. Coupled synthesis and self-assembly of nanoparticles to give structures with controlled organization. Nature 402, 393-395 (1999).

7. Bockstaller, M. R., Lapetnikov, Y., Margel, S. \& Thomas, E. L. Size-selective organization of enthalpic compatibilized nanocrystals in ternary block copolymer/particle mixtures. J. Am. Chem. Soc. 125, 5276-5277 (2003).

8. Shenton, W., Pum, D., Sleytr, U. B. \& Mann, S. Synthesis of cadmium sulphide superlattices using selfassembled bacterial S-layers. Nature 389, 585-587 (1997)

9. Mann, S. \& Ozin, G. A. Synthesis of inorganic materials with complex form. Nature 382, 313-318 (1996).

10. Thurn-Albrecht, T. et al. Ultrahigh-density nanowire arrays grown in self-assembled diblock copolymer templates. Science 290, 2126-2129 (2000).

11. Bockstaller, M., Kolb, R. \& Thomas, E. L. Metallodielectric photonic crystals based on diblock copolymers. Adv. Mater. 13, 1783-1786 (2001).

12. Black, C. T., Murray, C. B., Sandstrom, R. L. \& Sun, S. H. Spin-dependent tunneling in self-assembled cobalt-nanocrystal superlattices. Science 290, 1131-1134 (2000)

13. Sanchez, C. \& Lebeau, B. Design and properties of hybrid organic-inorganic nanocomposites for photonics. MRS Bull. 26, 377-387 (2001).

14. Alexandre, M. \& Dubois, P. Polymer-layered silicate nanocomposites: preparation, properties and uses of a new class of materials. Mater. Sci. Eng. Rev. 28, 1-63 (2000).

15. Soo, P. P. et al. Rubbery block copolymer electrolytes for solid-state rechargeable lithium batteries. J. Electrochem. Soc. 146, 32-37 (1999).

16. Balazs, A. C. Interactions of nanoscopic particles with phase-separating polymeric mixtures. Curr. Opin. Colloid Interf. Sci. 4, 443-448 (2000).

17. Lee, J. Y., Shou, Z. \& Balazs, A. C. Modeling the self-assembly of copolymer-nanoparticle mixtures confined between solid surfaces. Phys. Rev. Lett. 91, 136103 (2003).

18. Lee, J. Y., Shou, Z. \& Balazs, A. C. Predicting the morphologies of confined copolymer/nanoparticle mixtures. Macromolecules 36, 7730-7739 (2003).

19. Mansky, P., Liu, Y., Huang, E., Russell, T. P. \& Hawker, C. Controlling polymer-surface interactions with random copolymer brushes. Science 275, 1458-1460 (1997).

20. Meiners, J. C., Quintel-Ritzi, A., Mlynek, J., Elbs, H. \& Krausch, G. Adsorption of block-copolymer micelles from a selective solvent. Macromolecules 30, 4945-4951 (1997).

21. Li, Z. et al. Self-ordering of diblock copolymers from solution. J. Am. Chem. Soc. 118, 10892-10893 (1996).

22. Liu, Y. et al. Surface-induced ordering in asymmetric block copolymers. Macromolecules 27, 4000-4010 (1994).

23. Morkved, T. L. \& Jaeger, H. M. Thickness-induced morphology changes in lamellar diblock copolymer ultrathin films. Europhys. Lett. 40, 643-648 (1997).

24. Knoll, A., Magerle, R. \& Krausch, G. Phase behavior in thin films of cylinder-forming ABA block copolymers: Experiments. J. Chem. Phys. 120, 1105-1116 (2004).

25. Kim, S. H., Misner, M. J., Xu, T., Kimura, M. \& Russell, T. P. Highly oriented and ordered arrays from block copolymers via solvent evaporation. Adv. Mater. 16, 226-231 (2004).

26. Brandrup, J. \& Immergut, E. H. Polymer Handbook 3rd edn, VI/411-VI/434 (John Wiley \& Sons, New York, 1998).

27. Wong, K. K. W., Whilton, N. T., Colfen, H., Douglas, T. \& Mann, S. Hydrophobic proteins: synthesi and characterisation of organic-soluble alkylated ferritins. Chem. Commun., 1621-1622 (1998)

28. Raja, K. S. \& Wang, Q. Encyclopedia of Nanoscience and Nanotechnology 321-330 (Marcel Dekker, New York, 2004).

29. Alivisatos, A. P. Perspectives on the physical chemistry of semiconductor nanocrystals. J. Phys. Chem. 100, 13226-13239 (1996).

30. Meldrum, F. C., Wade, V. J., Nimmo, D. L., Heywood, B. R. \& Mann, S. Synthesis of inorganic nanophase materials in supramolecular protein cages. Nature 349, 684-687 (1991).

Supplementary Information accompanies the paper on www.nature.com/nature.

Acknowledgements We thank T. Xu, J. Sievert, K. Lavery, K. Schmidt, M. Hund, X. Hu, H. Skaff and J. Hirsch for their assistance with the experiments. This work was supported by the US

Department of Energy, the NSF-supported MRSEC at the University of Massachusetts Amherst, the NSF Collaborative Research in Chemistry Program, the NSF Career Award, the Army Research Office through a MURI, the NSF CRC programme, and the MAX KADE Foundation. The Advanced Photon Source is supported by the US Department of Energy.

Competing interests statement The authors declare that they have no competing financial interests.

Correspondence and requests for materials should be addressed to TPR

(russell@mail.pse.umass.edu).

\section{Mesozoic Alpine facies deposition as a result of past latitudinal plate motion}

\author{
Giovanni Muttoni ${ }^{1,2}$, Elisabetta Erba ${ }^{1}$, Dennis V. Kent ${ }^{3}$ \\ \& Valerian Bachtadse ${ }^{4}$
}

${ }^{1}$ Department of Earth Sciences, University of Milan, via Mangiagalli 34, I-20133 Milan, Italy

${ }^{2}$ ALP - Alpine Laboratory of Paleomagnetism, via Madonna dei Boschi 76, I-12016 Peveragno (CN), Italy

${ }^{3}$ Department of Geological Sciences, Rutgers University, Piscataway, New Jersey 08854, USA, and Lamont-Doherty Earth Observatory, Palisades, New York 10964, USA

${ }^{4}$ Department fuer Geo- und Umweltwissenschaften, Ludwig-MaximilliansUniversitaet Muenchen, Theresienstrasse 41, D-80333 Munich, Germany

The fragmentation of Pangaea as a consequence of the opening of the Atlantic Ocean is documented in the Alpine-Mediterranean region by the onset of widespread pelagic sedimentation ${ }^{1}$. Shallow-water sediments were replaced by mainly pelagic limestones in the Early Jurassic period, radiolarian cherts in the Middle-Late Jurassic period, and again pelagic limestones in the Late Jurassic-Cretaceous period ${ }^{1}$. During initial extension, basin subsidence below the carbonate compensation depth (CCD) is thought to have triggered the transition from Early Jurassic limestones to Middle-Late Jurassic radiolarites ${ }^{1}$. It has been proposed that the transition from radiolarites to limestones in the Late Jurassic period was due to an increase in calcareous nannoplankton abundance when the $\mathrm{CCD}$ was depressed below the ocean floor ${ }^{1}$. But in modern oceans, sediments below the CCD are not necessarily radiolaritic. Here we present palaeomagnetic samples from the Jurassic-Cretaceous pelagic succession exposed in the Lombardian basin, Italy. On the basis of an analysis of our palaeolatitudinal data in a broader palaeogeographic context, we propose an alternative explanation for the above facies tripartition. We suggest that the Lombardian basin drifted initially towards, and subsequently away from, a near-equatorial upwelling zone of high biosiliceous productivity. Our tectonic model for the genesis of radiolarites adds an essential horizontal plate motion component to explanations involving only vertical variations of CCD relative to the ocean floor. It may explain the deposition of radiolarites throughout the Mediterranean and Middle Eastern region during the Jurassic period.

Modern oceans are undersaturated with respect to silica ${ }^{2}$, and this causes the post-mortem dissolution of siliceous tests. Only under specific oceanic conditions, whereby the wind-driven upwelling of nutrient- and silica-rich deeper waters sustain enhanced plankton productivity, can a significant fraction of the siliceous biomass be buried before dissolution. Radiolarians in particular tend to proliferate in the equatorial belts of the Pacific and Indian oceans ${ }^{2}$. The hypothesis that Mesozoic Alpine facies changes resulted from past latitudinal plate motion across climate belts can be tested with palaeomagnetism. Rocks can acquire a magnetization parallel to the Earth's ambient geomagnetic field at the time of their formation. Because the time-averaged field is essentially dipolar, the inclination of the natural remanent magnetization with respect to the palaeohorizontal, represented by sedimentary bedding planes, is a function of palaeolatitude. We studied the palaeomagnetism of the Jurassic-Cretaceous pelagic succession exposed at Colle Sogno in the Lombardian basin (Fig. 1); this location was selected because of its relatively simple tectonic setting, quality of exposure and the stratigraphic continuity of strata of known age. The succession, biostratigraphically dated with nannofossils and ammonites (see 
refs 3 and 4, and references therein), was assigned numerical ages according to the timescale of ref. 5 (Fig. 2). The lower part of the succession consists of $450 \mathrm{~m}$ of shallow water limestones $(\mathrm{Zu}$ Formation-Conchodon Dolomite), $550-600 \mathrm{~m}$ of grey calcarenites and calcilutites with chert lenses and marly interbeds (Sedrina, Moltrasio and Domaro Formations) and $145 \mathrm{~m}$ of grey-pink pelagic limestones and marlstones (Sogno Formation), collectively of Rhaetian-early Bajocian age. The middle part consists of $20 \mathrm{~m}$ of ribbon-bedded green radiolarites, $15 \mathrm{~m}$ of red knobby radiolarites and $29 \mathrm{~m}$ of red cherty limestones (Rosso ad Aptici Formation), collectively of early Bajocian-late Tithonian age. The upper part consists of $150 \mathrm{~m}$ of nannofossil-rich calcilutites of the Maiolica Formation (Tithonian-Aptian). Sediment accumulation rates (not corrected for dewatering and burial compaction) are estimated at $\sim 30 \mathrm{~m} \mathrm{Myr}^{-1}$ in the Moltrasio-Domaro Formations, $12 \mathrm{~m} \mathrm{Myr}^{-1}$ in the Sogno Formation, $2-3 \mathrm{~m} \mathrm{Myr}^{-1}$ in the radiolarites-Rosso ad Aptici interval, and increasing to $6-7 \mathrm{~m} \mathrm{Myr}^{-1}$ in the Maiolica Formation (Fig. 2).

Oriented palaeomagnetic samples (191) were collected at 13 sites through the succession (Fig. 2, sites VC and CS1-CS11). Samples were thermally demagnetized (Supplementary Table A) in order to retrieve characteristic magnetization components (Supplementary Table B) and to calculate site-mean palaeomagnetic poles and palaeolatitudes with associated errors (Supplementary Table C) (see Methods). The time span covered by each sampling site ( $\sim 0.1-1.5 \mathrm{Myr})$ should be sufficient to average out secular variations. Literature data from the Domaro ${ }^{6}$ and Maiolica ${ }^{7-9}$ Formations of the Lombardian basin, projected to the Colle Sogno locality coordinates, augmented the definition of our palaeolatitude curve, and extended it into the Early Cretaceous.

The Lombardian basin composite palaeolatitude curve (Fig. 2; Supplementary Table C) shows a moderate southward drift from $35^{\circ} \mathrm{N}$ to $25^{\circ} \mathrm{N}$ in the Early Jurassic followed by a drop to values of $10^{\circ} \mathrm{N}$ and less in the Middle-Late Jurassic coincident with

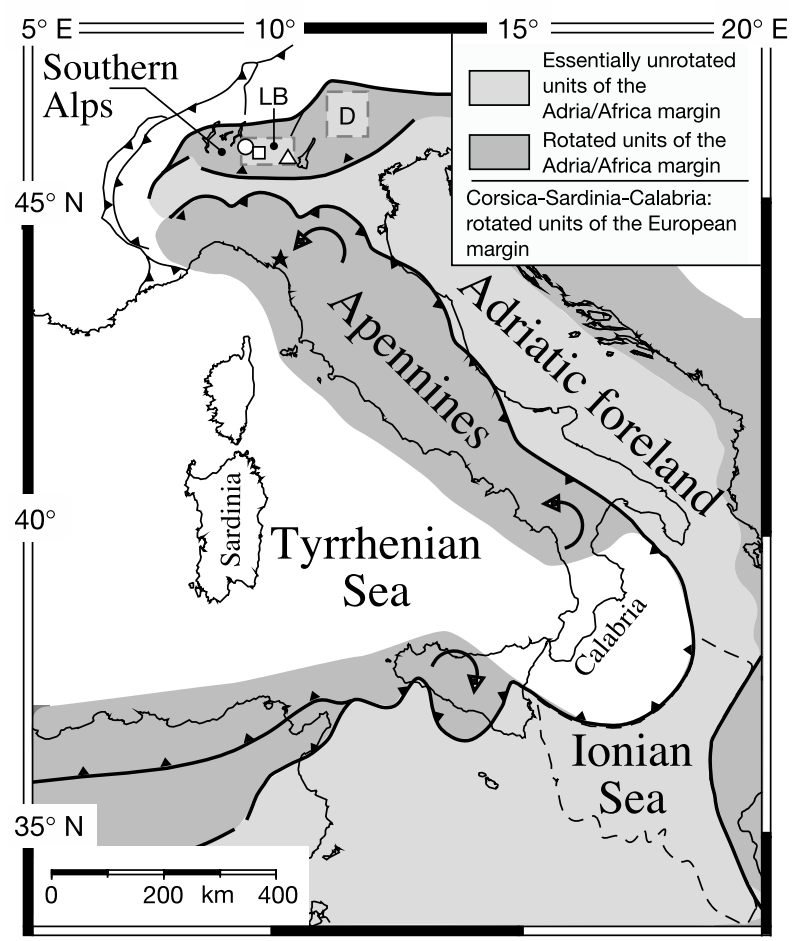

Figure 1 Structural map of Italy. Key palaeomagnetic sites from the Southern Alps and the Apennines discussed in the text are: open square, Valcava-Colle Sogno; open circle, Alpetto $^{7}$; open triangle, Piè del Dosso $0^{8}$; filled star, Tuscany ${ }^{10}$. D, Dolomites, LB, Lombardian basin. Site coordinates are in Supplementary Table C. radiolarite deposition (sites CS8-CS10). Near-equatorial latitudes during Middle-Late Jurassic deposition of radiolarites were also palaeomagnetically recorded outside the Lombardian basin in Tuscany $^{10}$ (Fig. 1). The mean palaeopole from these radiolarites is offset by $\sim 70^{\circ}$ anticlockwise from site CS8 of this study. This offset is due to vertical axis rotation with negligible latitudinal transport. Accordingly, we can incorporate data from the Tuscan radiolarites in the Lombardian basin palaeolatitude curve (TU1 and TU2; Fig. 2). Higher values of $20-30^{\circ} \mathrm{N}$ occurred in the Early Cretaceous during deposition of the Maiolica nannofossil ooze.

Sedimentary compaction may cause the palaeomagnetic inclination of some sediment to be shallower than the true inclination of the palaeomagnetic field. To check this possibility, palaeolatitudes from well-dated magmatic rocks from Africa and North America were rotated to northwest Africa coordinates using published Euler poles, and transferred to the Colle Sogno locality (Supplementary Table C). This transfer procedure is allowed by the palaeogeographic affinity of Adria and Africa, as demonstrated by the fact that the northern margin of Adria in the Lombardian basin and elsewhere in the Southern Alps, although locally deformed during the Alpine orogeny, has Permian-Mesozoic palaeomagnetic directions that are statistically indistinguishable from those of Africa ${ }^{11,12}$. Tropical latitudes for the Lombardian basin during the Early Jurassic are corroborated by data from magmatic rocks from Sierra Leone and Mauritania (data points $\mathrm{FR}^{13}, \mathrm{NM}$ and $\mathrm{SM}^{14}$ in Fig. 2). Nearequatorial latitudes in the Middle-Late Jurassic are supported by data from the Mzongwana kimberlite of South Africa dated at $152 \pm 3.4 \mathrm{Myr}$ ago $\left(\mathrm{MZ}^{15}\right)$. More tropical latitudes in the Early Cretaceous are confirmed by data from the Swartruggens Main kimberlite of South Africa $\left(\mathrm{SMA}^{15}\right)$, the Ithaca kimberlites $\left(\mathrm{NY}^{16}\right)$ of North America, the White Mountains plutons $\left(\mathrm{NE}^{17}\right)$ of North America, and the Group 2 kimberlites of South Africa $\left(\mathrm{G} 2 \mathrm{~K}^{15}\right)$ (Fig. 2; Supplementary Table C).

We placed the palaeolatitudinal evolution in a broader palaeogeographic perspective by calculating overall mean palaeopoles for Adria (Supplementary Table C) and restoring other Gondwanan and Laurasian elements relative to northwest Africa (Adria) using published Euler poles of rotation (Fig. 2, right panels) (see Methods). The rapid southward movement of Adria/Africa from the Early Jurassic (187-177 Myr ago) to the Middle-Late Jurassic (166-149 Myr ago) was broadly coeval with the opening of a seaway connecting the central Atlantic Ocean to the Tethys Ocean, which around Adria is called the Liguria-Piedmont Ocean. Inclinationonly palaeomagnetic data from the Middle East support our 166149 Myr reconstruction by indicating that the northern margin of Arabia was close to the Equator in the Late Jurassic-Early Cretaceous $^{18}$. The late Middle Jurassic to Late Jurassic was the time of maximum abundance of radiolarian-rich sediments in the AtlanticTethys seaway and surrounding margins at sites in Spain, the Alps, Carpathians, Adria and Greece, as well as in the Tethys Ocean facing $\mathrm{Oman}^{19,20}$. These sites were located at near-equatorial latitudes, presumably in a zone of high biosiliceous productivity sustained by upwelling of deeper waters enriched in nutrients and silica ${ }^{19,20}$, as observed in modern equatorial belts ${ }^{2}$. This is confirmed by a recent study of Jurassic Apennines radiolarites that indicates repeated periods of high primary productivity of surface waters sustained by nutrients remobilized by strong ocean circulation ${ }^{21}$. In the time span when the Atlantic-Tethys seaway resided at near-equatorial latitudes, the actual deposition of radiolarites depended also on local or regional palaeogeographic and/or palaeoecologic factors. Low fertility related to dominant antiestuarine-type circulation, relatively shallow water depth promoting preservation of carbonates, dilution by terrigenous input, or a combination of these factors, may explain the absence of true radiolarites in the young, land-locked subequatorial central Atlantic Ocean ${ }^{\text {e.g. } 20}$. The upper Middle-lower Upper Jurassic sections at Deep Sea Drilling Project Sites 367 and 534 consist in any case of radiolarian-rich intervals 


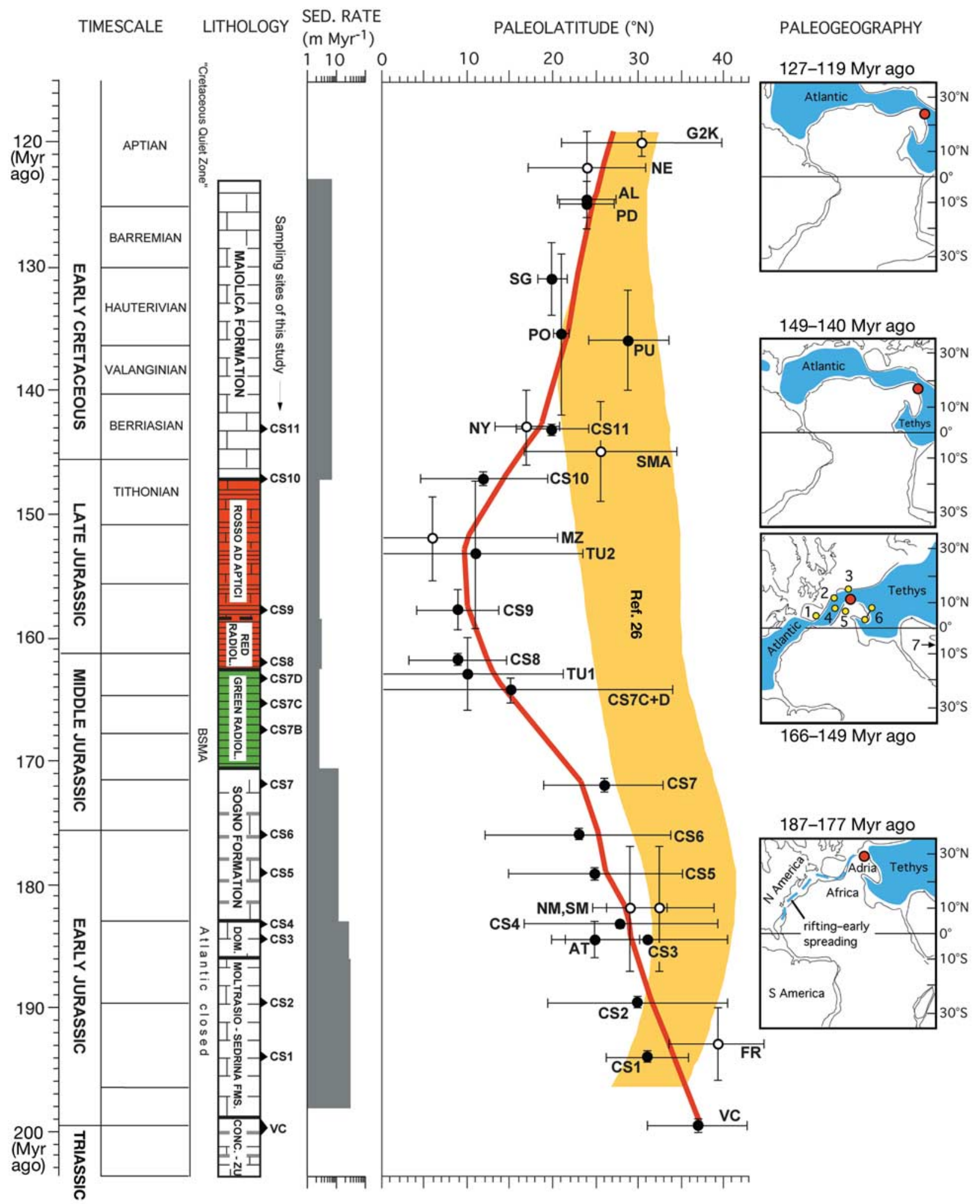

Figure 2 Palaeolatitudinal evolution of Colle Sogno. Left panels, timescale of ref. 5 with marine magnetic anomalies (M37-MOr; BSMA, Blake Spur) placed next to the Colle Sogno succession (CONC., Conchodon Dolomite; ZU, Zu Formation; DOM., Domaro Formation; RADIOL., radiolarites) with average sedimentation (SED.) rates. Central panels: palaeolatitudes from sediments (filled circles) and magmatic rocks (open circles; acronyms in Supplementary Table C) interpolated by the red line compared with palaeolatitudes from Besse and Courtillot ${ }^{26}$ (yellow band). Right panels: Adria's palaeogeography (oceanic crust in blue; see Methods); yellow circles: Spain (1), Swiss
Alps (2), Carpathians (3), western Alps-Liguria (4), Tuscany-Umbria (5), Greece (6), Oman (7); Lombardian basin: red circle. Horizontal error bars represent paleolatitude uncertainty expressed by \pm A95 (Fisher's cone of $95 \%$ confidence about the paleomagnetic pole) or approximated by $\pm d p$ (minor axis of Fisher's $95 \%$ confidence oval about the paleomagnetic pole) (see Methods and Supplementary Table C). Vertical error bars represent age coverage of palaeomagnetic sites derived from sediment accumulation rates estimates (see text). 
that suggest fertility regimes higher than in preceding and following intervals ${ }^{20}$.

Radiolarites deposited directly on exhumed serpentinized mantle rocks and pillow lavas are a key element of Alpine ophiolites in the so-called "Steinmann trinity" 22 . Oceanic gabbros from Corsica, Liguria and the eastern Alps occur in a narrow age window centred at $160 \mathrm{Myr}$ ago (see references in ref. 22) when the LiguriaPiedmont Ocean was at near-equatorial latitudes. This would explain why radiolarites rather than carbonates were deposited on the newly formed and thus presumably shallow oceanic crust.

Radiolarian cherts deposited in equatorial zones of ancient oceans are a diachronous facies controlled primarily by plate motion across oceanic zonal circulation patterns. Cherts deposited at near-equatorial palaeolatitudes in the Slide Mountain displaced terrane of British Columbia are late Palaeozoic in age ${ }^{23}$, and those of the Franciscan Complex accreted on the continental margin of California and Mexico are Jurassic in age ${ }^{24}$, whereas those deposited in response to the equatorial crossing of the Pacific plate are Late Jurassic and Cretaceous ${ }^{25}$. At Colle Sogno, oceanic sedimentation became progressively less siliceous and more calcareous in the Early Cretaceous (Fig. 2). Our data indicate that this widespread shift to dominant nannofossil oozes ${ }^{20}$ was triggered by the motion of Adria out of the near-equatorial upwelling belt into less trophic tropical waters dominated by calcareous nannoplankton.

Palaeomagnetic evidence has previously been presented ${ }^{11}$ for the swing to low latitudes of Adria by the latest Jurassic. We observe that this movement started earlier, in the Middle Jurassic, and was more pronounced than generally realized because, to our knowledge, palaeomagnetic data for Adria's radiolarites that were deposited at the lowest palaeolatitudes had not been reported before ref. 10 and this study. This interval of rapid plate motion is largely underestimated in conventional apparent polar wander paths (APWPs) based on running averages of palaeopole entries. For example, the most recent Besse and Courtillot ${ }^{26}$ master APWP transferred to Africa in the interval $170-145 \mathrm{Myr}$ ago includes palaeopoles from limestones from central Europe that have an ambiguous smeared distribution with a suspicion of remagnetization ${ }^{18}$, whereas welldated Adria poles were excluded from the compilation even though the tectonic affinity of parts of Adria to Africa is well demonstrated $^{11,12}$. As a result, latitudes predicted for Colle Sogno by this master APWP show little variation over the Jurassic-Early Cretaceous (Fig. 2).

Modern climate zonality provides a first-order hypothesis to explain ancient sedimentary facies that can be tested with palaeomagnetism. Paleolatitudinal data from a continuous succession of sediments at Colle Sogno show that carbonate facies dominated when Adria was located at tropical latitudes in the Early Jurassic, radiolarian oozes were deposited when it moved to near-equatorial latitudes in the Middle-Late Jurassic, and nannofossil oozes became progressively dominant when it returned to higher tropical latitudes in the Late Jurassic-Cretaceous. This tectonic model for the genesis of radiolarites on Adria's rifted margins adds an essential horizontal plate motion component to explanations involving only vertical variations of the CCD relative to the ocean floor ${ }^{1}$, which is an efficient mechanism for varying carbonate concentration rather than form radiolarian oozes.

\section{Methods}

\section{Samples and measurements}

Standard high-field thermomagnetic experiments show that samples from the lower part of the succession (dominantly grey $\mathrm{Zu}$ Limestone to lower Sogno Formation) contain magnetite with moderate coercivity and maximum unblocking temperatures $\left(T_{\max }\right)$ of $\sim 570^{\circ} \mathrm{C}$ in association with subsidiary haematite with higher coercivity and a $T_{\max }$ of $\sim 680^{\circ} \mathrm{C}$ (Supplementary Fig. A). A magnetite-haematite mixture dominates the grey to pink upper Sogno Formation, magnetite associated with subsidiary haematite

characterizes the green and red radiolarites, a magnetite-haematite mixture dominates the reddish Rosso ad Aptici Formation, and magnetite alone characterizes the white Maiolica Formation.
All samples were thermally demagnetized and analysed at the palaeomagnetic laboratory of the University of Munich (Supplementary Table A). The extremely weak magnetization of the Colle Sogno samples $\left(0.1-15 \mathrm{~mA} \mathrm{~m}^{-1}\right)$ required the use of highly sensitive magnetometers with d.c. SQUID technology. Demagnetization showed the initial removal of an overprint component usually aligned along the present-day magnetic field and a final characteristic component over higher demagnetization temperatures that is compatible with magnetite and occasionally haematite as the remanence carriers (Supplementary Fig. B). The characteristic magnetization, calculated by means of principal component analysis, has dual polarity, being oriented northerly-and-down or southerly-and-up (Supplementary Table B). It was observed in samples from all sites (except site CS7B) and showed no discernible change in orientation with respect to the origin of the axes of orthogonal projection plots in mixed mineralogy samples. Other magnetization components observed in some samples over intermediate unblocking temperatures $\left(200-550^{\circ} \mathrm{C}\right)$ are usually scattered between the present-day field and the characteristic magnetization directions, suggesting that they represent composite magnetizations, although overprinting during the Alpine orogeny may be a contributing factor.

\section{Data analysis}

The characteristic components of magnetization, grouped in three distinct stratigraphic intervals (Domaro Formation, radiolarites-basal Rosso ad Aptici, and upper Rosso ad Aptici-basal Maiolica) by means of standard Fisher statistics, pass the polarity reversal test (class $\mathrm{C}$ of ref. 27). The generally homogeneous bedding attitudes preclude the application of a fold test at Colle Sogno. Two magnetostratigraphically correlated sections from the Maiolica Formation at Alpetto and Piè del Dosso ${ }^{7,8}$, located respectively west and east of Colle Sogno (Fig. 1), have characteristic mean directions that differ by $105^{\circ}$ in geographic coordinates but only $4^{\circ}$ in tilt-corrected coordinates. These tilt-corrected magnetizations, similar in orientation to the ones from the basal Maiolica Formation at site CS11, pre-date Alpine folding and suggest internal structural consistency of this part of the South Alpine belt. We therefore interpret the dual-polarity directions from Colle Sogno as primary magnetizations acquired in normal and reverse polarity geomagnetic fields.

Fisher statistics were applied to calculate site mean characteristic component directions. From the characteristic component of each sample, a virtual geomagnetic pole was calculated and Fisher statistics were applied to calculate site mean palaeomagnetic poles. Palaeolatitudes were calculated as $90^{\circ}$ minus colatitude, where colatitude is the arc distance between the Colle Sogno average palaeomagnetic site and the individual palaeomagnetic north poles, with palaeolatitude error defined by \pm A95 (Fisher's cone of $95 \%$ confidence about the palaeomagnetic pole) (Supplementary Table C).

Fisher statistics were applied to calculate selected overall mean palaeomagnetic poles for Adria (Supplementary Table C) for palaeogeographic reconstructions (Fig. 2, right panels). Rotation poles of Gondwanan elements relative to northwest Africa (Adria) are from ref. 28, rotation poles of Laurasian elements relative to Adria are from ref. 29, and rotation poles of North America relative to Africa are from ref. 29 for pre-oceanic spreading time and from ref. 30 for syn-oceanic spreading times. The reconstructions at 166-149 Myr ago, 149-140 Myr ago and 127-119 Myr ago use, respectively, magnetic anomalies M25 ( $\sim 155$ Myr ago), M21-M16 (interpolated mid-value at $\sim 144.5 \mathrm{Myr}$ ago) and $\mathrm{M} 0(\sim 125 \mathrm{Myr}$ ago $)$.

Received 17 June 2004; accepted 6 January 2005; doi:10.1038/nature03378.

1. Winterer, E. L. \& Bosellini, A. Subsidence and sedimentation on Jurassic passive continental margin, Southern Alps, Italy. Bull. Am. Assoc. Petrol. Geol. 65, 394-421 (1981).

2. Kennett, J. P. Marine Geology (Prentice-Hall, Englewood Cliffs, 1982)

3. Baumgartner, P. et al. New Middle and Upper Jurassic radiolarian assemblages co-occurring with ammonites and nannofossils from Southern Alps (northern Italy). Mem. Geol. (Lausanne) 23, 737-750 (1995).

4. Erba, E. Nannofossils and Mesozoic oceanic anoxic events. Mar. Micropaleontol. 52, 85-106 (2004).

5. Gradstein, F. M. et al. A new geologic time scale, with special reference to Precambrian and Neogene. Episodes 27, 83-100 (2004)

6. Horner, F. \& Heller, F. Lower Jurassic magnetostratigraphy at the Breggi Gorge (Ticino, Switzerland) and Alpe Turati (Como, Italy). Geophys. J. R. Astron. Soc. 73, 705-718 (1983).

7. Channell, J. E. T., Cecca, F. \& Erba, E. Correlations of Hauterivian and Barremian (Early Cretaceous) stage boundaries to polarity chrons. Earth Planet. Sci. Lett. 134, 125-140 (1995).

8. Channell, J. E. T. \& Erba, E. Early Cretaceous polarity chrons CM0 to CM11 recorded in northern Italian land sections near Brescia. Earth Planet. Sci. Lett. 108, 161-179 (1992).

9. Channell, J. E. T., Erba, E. \& Lini, A. Magnetostratigraphic calibration of the Late Valanginian carbon isotope event in pelagic limestones from Northern Italy and Switzerland. Earth Planet. Sci. Lett. 118, 145-166 (1993).

10. Aiello, I. W. \& Hagstrum, J. T. Paleomagnetism and paleogeography of Jurassic radiolarian cherts from the northern Apennines of Italy. Geol. Soc. Am. Bull. 113, 469-481 (2001).

11. Channell, J. E. T. in Palaeomagnetism and Tectonics of the Mediterranean Region (eds Morris, A. \& Tarling, D. H.) 119-132 (Geological Society Special Publication, London, 1996).

12. Muttoni, G. et al. Early Permian Pangea 'B' to Late Permian Pangea 'A'. Earth Planet. Sci. Lett. 215, 379-394 (2003).

13. Hargraves, R. B., Briden, J. C. \& Daniels, B. A. Palaeomagnetism and magnetic fabric in the Freetown Complex, Sierra Leone. Geophys. J. Int. 136, 705-713 (1999).

14. Sichler, J. L. et al. Mobility of Morocco. Can. J. Earth Sci. 17, 1546-1558 (1980).

15. Hargraves, R. B. Paleomagnetism of Mesozoic kimberlites in Southern Africa and the Cretaceous apparent polar wander curve for Africa. J. Geophys. Res. 94, 1851-1866 (1989).

16. Van Fossen, M. C. \& Kent, D. V. A palaeomagnetic study of 143 Ma kimberlite dikes in central New York State. Geophys. J. Int. 113, 175-185 (1993).

17. Van Fossen, M. C. \& Kent, D. V. Paleomagnetism of 122 Ma plutons in New England and the MidCretaceous paleomagnetic field in North America; true polar wander or large-scale differential mantle motion? J. Geophys. Res. 97, 19651-19661 (1992). 
18. Van der Voo, R. Paleomagnetism of the Atlantic, Tethys and Iapetus Oceans (Cambridge University Press, Cambridge, 1993)

19. De Wever, P., Azéma, J. \& Fourcade, E. Radiolaires et radiolarites: production primaire, diagenèse et paléogéographie. Bull. Centres Rech. Explor. Product. Elf Aquitaine 18, 315-379 (1994).

20. Baumgartner, P. O. Age and genesis of Tethyan Jurassic Radiolarites. Eclog. Geol. Helv. 80, 831-879 (1987).

21. Bartolini, A., Baumgartner, P. O. \& Guex, J. Middle and Late Jurassic radiolarian palaeoecology versu carbon-isotope stratigraphy. Palaeogeogr. Palaeoclimatol. Palaeoecol. 145, 43-60 (1999).

22. Bernoulli, D., Manatschal, G., Desmurs, L. \& Muenterer, O. Where did Gustav Steinmann see the trinity? Back to the roots of an Alpine ophiolite concept. Geol. Soc. Am. Spec. Pap. 373, 93-110 (2003).

23. Richards, D., Butler, R. F. \& Harms, T. A. Paleomagnetism of the late Paleozoic Slide Mountain terrane, northern and central British Columbia. Can. J. Earth Sci. 30, 1898-1913 (1993).

24. Hagstrum, J. T. \& Murchey, B. L. Deposition of Franciscan Complex cherts along the paleoequator and accretion to the American margin at tropical paleolatitudes. Geol. Soc. Am. Bull. 105, 766-778 (1993).

25. Larson, R. L., Steiner, M. B., Erba, E. \& Lancelot, Y. Paleolatitudes and tectonic reconstructions of the oldest portion of the Pacific Plate: A comparative study. Proc. ODP. Sci. Res. 129, 615-631 (1992)

26. Besse, J. \& Courtillot, V. Correction to "Apparent and true polar wander and the geometry of the geomagnetic field over the last 200 Myr". J. Geophys. Res. Solid Earth 108, 2469, doi:10.1029/ 2003JB002684 (2003)

27. McFadden, P. L. \& Lowes, F. J. The discrimination of mean directions drawn from Fisher distributions. Geophys. J. R. Astron. Soc. 67, 19-33 (1981).

28. Lottes, A. L. \& Rowley, D. B. in Palaeozoic Palaeogeography and Biogeography (eds McKerrow, W. S. \& Scotese, C. R.) 383-395 (Memoir 12, Geological Society of London, 1990).

29. Bullard, E. C., Everett, J. \& Smith, A. G. The fit of the continents around the Atlantic. Phil. Trans. R. Soc. Lond. A 258, 41-45 (1965).

30. Klitgord, K. D. \& Schouten, H. in The Geology of North America, The Western North Atlantic Region (eds Vogt, P. R. \& Tucholke, B. E.) 351-377 (Geological Society of America, Boulder, 1986)

Supplementary Information accompanies the paper on www.nature.com/nature

Acknowledgements E. Dallanave is thanked for assistance in the field and laboratory analysis. Comments by D. Bernoulli and J. Hagstrum greatly improved the manuscript.

Competing interests statement The authors declare that they have no competing financial interests.

Correspondence and requests for materials should be addressed to G.M. (giovanni.muttonil@unimi.it).

\section{Insolation-driven changes in} atmospheric circulation over the past 116,000 years in subtropical Brazil

Francisco W. Cruz Jr ${ }^{1,2}$, Stephen J. Burns ${ }^{1}$, Ivo Karmann ${ }^{2}$,

Warren D. Sharp ${ }^{3}$, Mathias Vuille ${ }^{1}$, Andrea O. Cardoso ${ }^{4}$, José A. Ferrari ${ }^{5}$, Pedro L. Silva Dias ${ }^{4}$ \& Oduvaldo Viana Jr $^{2}$

${ }^{1}$ Department of Geosciences, University of Massachusetts, Amherst, 01002 Massachusetts, USA

${ }^{2}$ Instituto de Geociências, Universidade de São Paulo, Rua do Lago 562, São Paulo, SP, 05508-080, Brazil

${ }^{3}$ Berkeley Geochronology Center, 2455 Ridge Rd, Berkeley, California 94709, USA ${ }^{4}$ Departamento de Ciências Atmosféricas, Instituto de Astronomia, Geofísica e Ciências Atmosféricas, Universidade de São Paulo, Rua do Matão 1226, São Paulo, SP 05508-090, Brazil

${ }^{5}$ Instituto Geológico, Av. Miguel Stefano 3900, São Paulo, SP 04301-903, Brazil

During the last glacial period, large millennial-scale temperature oscillations-the 'Dansgaard/Oeschger' cycles-were the primary climate signal in Northern Hemisphere climate archives from the high latitudes to the tropics ${ }^{1-6}$. But whether the influence of these abrupt climate changes extended to the tropical and subtropical Southern Hemisphere, where changes in insolation are thought to be the main direct forcing of climate, has remained unclear. Here we present a high-resolution oxygen isotope record of a U/Th-dated stalagmite from subtropical southern Brazil, covering the past 116,200 years. The oxygen isotope signature varies with shifts in the source region and amount of rainfall in the area, and hence records changes in atmospheric circulation and convective intensity over South America. We find that these variations in rainfall source and amount are primarily driven by summer solar radiation, which is controlled by the Earth's precessional cycle. The Dansgaard/ Oeschger cycles can be detected in our record and therefore we confirm that they also affect the tropical hydrological cycle, but that in southern subtropical Brazil, millennial-scale climate changes are not as dominant as they are in the Northern Hemisphere.

The study area in subtropics of southeastern Brazil is wellsituated for investigating changes in tropical and subtropical atmospheric circulation. Although wet and dry seasons are not observed, the region receives rainfall from two distinct sources in different seasons (see Supplementary Information S1). During the austral winter and early spring, equatorward incursions of midlatitude cold dry air result in cyclonic storms that move moisture inland from the nearby Atlantic Ocean ${ }^{7}$. During the late summer and early autumn, rainfall is related to the intense convection over the interior Amazon basin that is associated with the South American summer monsoon (SASM) ${ }^{8}$. From December to March, a northwesterly low-level flow, the Andean low-level jet (ALLJ), transports Amazon tropical moisture from interior Brazil near the Equator towards the South Atlantic Convergence Zone (SACZ) located over southern Brazil ${ }^{9}$. At the study site $\left(27^{\circ} \mathrm{S}\right)$, a significant fraction of summer precipitation derives from this moisture flux ${ }^{10}$.

Thus, although it is not directly beneath the centre of convective activity over the Amazon basin, summer rainfall in southeastern Brazil is strongly influenced by the southward progression of convection across the Amazon basin through the summer. The two sources of rainfall also have quite distinct oxygen isotopic ratios. The more locally sourced winter rainfall is enriched in ${ }^{18} \mathrm{O}$ compared to summer precipitation, with average $\delta^{18} \mathrm{O}$ values of precipitation during the winter of $-3 \%$ as compared to average values of $-7 \%$ in the early autumn at Porto Alegre City, southern Brazil $^{11}$ (and see Supplementary Information S2). At present the mean annual isotopic composition of rainfall is mainly determined by the relative contribution of summer, monsoonal precipitation versus winter, extratropical precipitation and not by temperature or amount effects. This interpretation is supported by the coincidence of more positive values of $\delta^{18} \mathrm{O}$ with the rainiest period in Porto Alegre during winter and early spring, which is contrary to the expected tendency if either temperature or precipitation amount were the major source of variation in rainfall oxygen isotope ratios $^{12}$.

Stalagmite BT2 was collected from Botuverá Cave $\left(27^{\circ} 13^{\prime} 24^{\prime \prime} \mathrm{S}\right.$; $49^{\circ} 09^{\prime} 20^{\prime \prime} \mathrm{W}, 230 \mathrm{~m}$ above sea level, a.s.l.). On the basis of $20 \mathrm{U} / \mathrm{Th}$ analyses, the 70 -cm-long stalagmite was deposited from $\sim 116$ thousand years (kyr) ago to the present without detectable hiatuses (Fig. 1). Samples for stable isotopic analyses were taken every $1 \mathrm{~mm}$, which represents an average resolution of $\sim 150 \mathrm{yr}$. Values of $\delta^{18} \mathrm{O}$ for stalagmite BT2 range from -0.5 to -5.0 with an apparent cyclicity of $\sim 20 \mathrm{kyr}$ (Fig. 2). The lowest values are observed around 14-20 kyr ago and around 40-45 kyr ago. Superimposed on the longer-term cyclicity are more abrupt millennial-scale variations with an amplitude of $\sim 1$ to $1.5 \%$.

Stalagmite BT2 appears to have been deposited in approximate isotopic equilibrium with cave drip water as indicated by the relatively small ranges of $\delta^{18} \mathrm{O}$ along single speleothem (such as stalactites or stalagmites) layers ${ }^{13}$ (S3a) and absence of significant correlations between $\delta^{18} \mathrm{O}$ and $\delta^{13} \mathrm{C}$ (Supplementary Information $\mathrm{S} 3 \mathrm{~b}$ and c). The relatively large range of variation in $\delta^{18} \mathrm{O}$, more than $5 \%$ in the speleothem, also suggests that temperature, through its effect in the calcite-water fractionation factor, is not the primary cause of the observed variation. The temperature-dependent fractionation between calcite and water is $-0.24 \%$ o per ${ }^{\circ} \mathrm{C}$ (ref. 14), requiring $20^{\circ} \mathrm{C}$ of temperature change to explain the total range of variation in $\delta^{18} \mathrm{O}$, or more than twice what is thought to be the total 
calreticulin/LDL receptor-related protein co-complex stimulates random and directed cell migration. J. Cell Sci. 116, 2917-2927 (2003).

19. Lee, H., Goetzl, E. J. \& An, S. Lysophosphatidic acid and sphingosine 1-phosphate stimulate endothelial cell wound healing. Am. J. Physiol. Cell Physiol. 278, C612-C618 (2000).

20. Schwab, A., Schuricht, B., Seeger, P., Reinhardt, J. \& Dartsch, P. C. Migration of transformed renal epithelial cells is regulated by $\mathrm{K}^{+}$channel modulation of actin cytoskeleton and cell volume. Pflugers Arch. 438, 330-337 (1999).

21. Schwab, A. Function and spatial distribution of ion channels and transporters in cell migration. Am. J. Physiol. Renal Physiol. 280, F739-F747 (2001).

22. Rosengren, S., Henson, P. M. \& Worthen, G. S. Migration-associated volume changes in neutrophils facilitate the migratory process in vitro. Am. J. Physiol. 267, C1623-C1632 (1994).

23. Lauffenburger, D. A. \& Horwitz, A. F. Cell migration: a physically integrated molecular process. Cell 84, 359-369 (1996).

24. Condeelis, J. Life at the leading edge: the formation of cell protrusions. Annu. Rev. Cell Biol. 9, 411-444 (1993).

25. Yang, B., Brown, D. \& Verkman, A. S. The mercurial insensitive water channel (AQP-4) forms orthogonal arrays in stably transfected Chinese hamster ovary cells. J. Biol. Chem. 271, 4577-4580 (1996).

26. Ma, T. et al. Severely impaired urinary concentrating ability in transgenic mice lacking aquaporin-1 water channels. J. Biol. Chem. 273, 4296-4299 (1998).

27. Papadopoulos, M. C., Manley, G. T., Krishna, S. \& Verkman, A. S. Aquaporin-4 facilitates reabsorption of excess fluid in vasogenic brain edema. FASEB J. 18, 1291-1293 (2004).

28. Kawamoto, A. et al. Intramyocardial transplantation of autologous endothelial progenitor cells for therapeutic neovascularization of myocardial ischemia. Circulation 107, 461-468 (2003).

Supplementary Information accompanies the paper on www.nature.com/nature.

Acknowledgements This work was funded by grants from the National Institutes of Health (to A.S.V.) and by a Wellcome Trust Clinician Scientist Fellowship (to M.C.P., sponsored by S. Krishna).

Competing interests statement The authors declare that they have no competing financial interests.

Correspondence and requests for materials should be addressed to A.S.V.

(verkman@itsa.ucsf.edu).

\section{erratum}

\section{Mesozoic Alpine facies deposition as a result of past latitudinal plate motion}

Giovanni Muttoni, Elisabetta Erba, Dennis V. Kent \& Valerian Bachtadse

Nature 434, 59-63 (2005).

In Fig. 2 of this Letter, several labels were missing. In the timescale columns on the left, the marine magnetic anomalies were incomplete (they should read, from the bottom up: Atlantic closed, BSMA, M37, M22, M17, M16, M15, M11, M3, M1, M0r, "Cretaceous Quiet Zone"), as were the stages (they should read, from the bottom up: RHAETIAN, HETTANGIAN, SINEMURIAN, PLIENSBACHIAN, TOARCIAN, AALENIAN, BAJOCIAN, BATHONIAN, CALLOVIAN, OXFORDIAN, KIMMERIDGIAN, TITHONIAN...). For the positions of the missing labels, please see the HTML version of the original paper on Nature's website (www.nature.com/nature/ journal/v434/n7029/full/nature03378_fs.html), where Fig. 2 has been corrected. addendum

Strong polarization enhancement in asymmetric three-component ferroelectric superlattices

\section{Ho Nyung Lee, Hans M. Christen, Matthew F. Chisholm, Christopher M. Rouleau \& Douglas H. Lowndes}

Nature 433, 395-399 (2005).

It has been drawn to our attention that in our Letter we may have inadvertently underplayed the significance of an earlier experimental study (ref. 11) through an unfortunate choice of wording. Our intention was not to claim the first experimental realization of asymmetric properties in a three-component superlattice (ref. 11 claimed a similar realization), but the first experimental observation of strain-enhanced ferroelectric polarization in such structures. 